JRPB, Vol. 6, No. 2, September 2018, Hal. 114-124

DOI: https://doi.org/10.29303/jrpb.v6i2.83

ISSN 2301-8119, e-ISSN 2443-1354

Tersedia online di http://jrpb.unram.ac.id/

\title{
ANALISIS KEEKONOMIAN PENGOPERASIAN ALAT PERONTOK UNTUK KEDELAI (STUDI KASUS: KECAMATAN MAJALENGKA, KABUPATEN MAJALENGKA)
}

\author{
Economyc Analysis of Soybean Thresher Operation \\ (Case Studies: Majalengka Subdistrict, Majalengka Regency) \\ Novi Dewi Sartika ${ }^{1, *}$, Sutrisno $^{1}$, Emmy Darmawati $^{1}$ \\ Departemen Teknik Mesin dan Biosistem, Institut Pertanian Bogor \\ Email $^{*}$ : novidewisartika@gmail.com \\ Diterima: Mei 2018 \\ Disetujui: September 2018
}

\begin{abstract}
Majalengka is one of the regency that had implemented the multipurpose threshers for soybean. The multipurpose thresher related with business sustainability in the region, so an economic analysis need to be done. The objective of this study was to assess the economics of multipurpose threshers in order to improve postharvest activity by using this multipurpose thresher. This research was conducted by operating two type of multipurpose threshers in the Sindang Kasih village as main soybean seed producing center. Thresher testing was done by setting the rotary cylinders speed on 515-570 rpm and 580-650 rpm. Weight losses of threshing operation was found 0.68-3.1\%. The results of analysis for main operational cost was Rp 327 - Rp 369/kg, and BEP was reached at 15.7-19.2 ha/year that equal with 23,562 - 28,852 kg of soybean seeds/year or Rp 9,604,100 - Rp 11,540,649/year. The equipment rent cost of $R p$ 400/kg was feasible with NPV Rp 1,997,037 - Rp 6,523,947, IRR 19.63-32.42\% and net B/C of 1.11-1.43. An availability of soybean to be threshed was found during two periods of planting, namely 40 ha on February until April and 10 ha on June until August.
\end{abstract}

Keywords: economic analysis, soybean, thresher, postharvest

\begin{abstract}
ABSTRAK
Kabupaten Majalengka merupakan salah satu wilayah yang telah menerapkan teknologi perontokan kedelai dengan menggunakan mesin multiguna. Mesin multiguna yang dioperasikan sangat terkait dengan keberlangsungan usaha perontokan di wilayah tersebut, sehingga analisis ekonomi perlu dilakukan. Tujuan penelitian ini adalah mengkaji keekonomian mesin perontok multiguna untuk mendukung perbaikan pascapanen melalui pengembangan dan penggunaan mesin multiguna. Penelitian ini dilakukan dengan mengoperasikan dua mesin perontok multiguna di desa Sindang Kasih yang merupakan daerah penghasil benih kedelai. Pengujian operasional mesin perontok dilakukan dengan mengatur kecepatan putar silinder pada 515-570 rpm dan 580-
\end{abstract}


$650 \mathrm{rpm}$. Susut bobot yang diperoleh dari pengoperasian alat adalah 0,68-3,1\%. Hasil analisis biaya pokok operasional alat dengan susut yang diperoleh sebesar Rp 327 - Rp 369/kg. BEP tercapai pada luasan lahan 15,7-19,2 ha/tahun yang setara dengan 23.562 - $28.852 \mathrm{~kg}$ biji kedelai/tahun atau sebesar Rp 9.604.100 - Rp 11.540.649/tahun. Sewa alat yang berlaku, yaitu Rp 400/kg, sudah layak dengan NPV Rp 1.997.037 - Rp 6.523.947, IRR 19,63 - 32,42\% dan net B/C 1,11-1,43. Ketersediaan bahan baku kedelai brangkasan yang dirontokkan oleh kedua mesin perontok didapatkan dalam dua periode tanam, yaitu bulan Februari-April sebesar 40 ha dan bulan Juni-Agustus sebesar 10 ha.

Kata kunci: analisis keekonomian, kedelai, mesin perontok, pascapanen

\section{PENDAHULUAN}

Tingkat konsumsi kedelai di Indonesia semakin meningkat. Ini ditunjukkan dengan pertumbuhan impor kedelai yang mencapai 1.04 juta ton pada tahun 2017. Peningkatan ini lebih tinggi dibandingkan tahun 2016 yaitu, hanya mencapai 767.3 ribu ton (BPS 2017). Upaya peningkatan produksi kedelai dalam negeri terus dilakukan untuk mengurangi ketergantungan impor yang terus meningkat. Selain di bidang budidaya, perbaikan dilakukan juga pada bidang pascapanen.

Salah satu penanganan pascapanen yang penting adalah kegiatan perontokan. Sejalan dengan perkembangan teknologi, alat perontok pun semakin berkembang. Mesin perontok yang digunakan penjual jasa alsintan umumnya bersifat multiguna, sehingga dapat digunakan untuk merontokan padi, kedelai, dan juga untuk memipil jagung. Dengan demikian, mesin perontok ini harus dioperasikan dengan hati-hati sesuai dengan komoditasnya, agar diperoleh susut yang serendah mungkin. Menurut Chenglong dkk. (2011) penggunaan mesin perontok (thresher) dapat mengurangi biji rusak, mengurangi biji yang tidak terontok, dan tingkat ketelitiannya yang cukup tinggi.

Wilayah penghasil kedelai di Indonesia yang memberikan kontribusi terbesar untuk kedelai Nasional adalah wilayah Jawa yang mencapai angka 521.954 ton pada tahun 2013 (BPS 2013). Salah satu wilayah di pulau Jawa tersebut adalah wilayah Jawa Barat. Wilayahwilayah yang dicanangkan untuk pengembangan pertanaman kedelai di provinsi ini adalah kabupaten Cianjur, Ciamis, Garut, Kuningan, Kerawang, dan Majalengka dengan luas lahan masing-masing $4130 \mathrm{Ha}, 2769 \mathrm{Ha}$, $7236 \mathrm{Ha}, 1370 \mathrm{Ha}, 1039 \mathrm{Ha}$, dan $1116 \mathrm{Ha}$ (DIPERTA 2013). Semua wilayah ini hampir memiliki tingkat kesuburan tanah dan curah hujan yang sama. Penanganan pasca panen terutama pada kegiatan perontokan di kabupaten Majalengka telah menerapkan teknologi mekanis dengan menggunakan mesin perontok multiguna. Analisis keekonomian mesin perontok multiguna perlu dilakukan untuk mengetahui biaya operasional yang menguntungkan agar dapat dijadikan acuan untuk pengoperasian mesin perontok setipe di wilayah penghasil kedelai yang sedang dikembangkan seperti wilayah Sumatra.

Tujuan penelitian ini adalah mengkaji keekonomian alat perontok multiguna untuk mendukung perbaikan pascapanen melalui pengembangan dan penggunaan alat perontok multiguna.

\section{METODE PENELITIAN}

Bahan yang digunakan adalah kedelai brangkasan dengan umur panen 80 hari. Kedelai brangkasan diperoleh langsung dari kelompok tani Bojong dan Mekar tani. Total berat kedelai brangkasan \pm 4 ton dengan varietas Argomulyo. Alat yang digunakan meliputi mesin perontok multiguna (power thresher), moisture tester, tachometer, stopwatch, terpal pengamatan berukuran $8 \mathrm{~m} \mathrm{x}$ 
$8 \mathrm{~m}$, dan terpal yang biasa digunakan oleh petani.

\section{Pengoperasian Alat Perontok}

Perontokan kedelai dilakukan dengan menggunakan dua mesin perontok multiguna, yaitu mesin bantuan pemerintah untuk kelompok tani Bojong (thresher A) dan mesin milik pribadi petani yang disewakan (thresher B). Spesifikasi masing-masing mesin perontok disajikan pada Tabel 1. Pengoperasian alat diatur dengan kecepatan putar silinder perontok 515-570 rpm dan 580-650 rpm dengan 2 kali ulangan. Langkah-langkah untuk memperoleh parameter susut bobot (tercecer) disajikan pada Gambar 1. Perhitungan besarnya susut bobot pada setiap kecepatan putar silinder perontok menggunakan Persamaan:

$$
\begin{aligned}
& \left.\mathrm{SPM}=\frac{\mathrm{BKT}_{\mathrm{pm}}+\mathrm{T}_{1 \text { mekanis }}+\mathrm{T}_{2 \text { mekanis }}}{\mathrm{BKH}_{\mathrm{pm}}+\mathrm{BKT}_{\mathrm{pm}}+\mathrm{T}_{1 \text { mekanis }}+\mathrm{T}_{2 \text { mekanis }}} \times 100 \% \cdot 1\right) \\
& \mathrm{T}_{1 \text { mekanis }}=\frac{\mathrm{B}_{1 \text { mekanis }}}{\text { Berat sampel brangkasan (1 kg) }} \times \mathrm{B}_{\text {mekanis }} \cdots . .2 \text { 2) } \\
& \left.\mathrm{T}_{2 \text { mekanis }}=\frac{\mathrm{C}_{1 \text { mekanis }}}{\text { Berat sampel kotoran }(1 \mathrm{~kg})} \times \mathrm{C}_{\text {mekanis }} \cdots \cdots \cdots . . . .3\right)
\end{aligned}
$$

Keterangan:

STM : Susut perontokan mekanis (\%)

$\mathrm{BKH}_{\mathrm{pm}} \quad$ : Berat kedelai hasil perontokan pada alas petani $(\mathrm{kg})$

$\mathrm{BKT}_{\mathrm{pm}} \quad$ : Berat kedelai yang terlempar keluar alas petani $(\mathrm{kg})$

$\mathrm{T}_{1 \text { mekanis }} \quad$ : Berat kedelai yang tidak terontok (gram)

$\mathrm{T}_{2 \text { mekani }} \quad$ : Berat biji kedelai yang terbuang/terbawa kotoran (gram)

$\mathrm{B}_{\text {mekanis }} \quad$ : Berat brangkasan perontokan keseluruhan $(\mathrm{kg})$

$\mathrm{C}_{\text {mekanis }} \quad$ : Berat kotoran sisa perontokan keseluruhan $(\mathrm{kg})$

$\mathrm{B}_{1 \text { mekanis }}$ : Biji kedelai yang dipisahkan dari polong sampel $1 \mathrm{~kg}$ (gram)

$\mathrm{C}_{1 \text { mekanis }}$ : Biji kedelai yang dipisahkan dari sampel kotoran $1 \mathrm{~kg}$ (gram)

\section{Analisis Ekonomi}

Mesin perontok yang digunakan di kabupaten Majalengka berumur ekonomis 5 tahun dengan harga alat sebesar Rp 18.000.000 untuk thresher A dan Rp 15.000.000 untuk thresher B. Biaya variabel pada kegiatan perontokan ini terdiri dari upah operator, biaya pemeliharaan alat, biaya bahan bakar (bensin), dan biaya pemindahan mesin (moving alat). Biaya tetap terdiri dari biaya penyusutan (10\% dari modal awal) dan bunga modal (15\% sesuai dengan investasi suku bunga bank BRI tahun 2013). Analisis keekonomian dilakukan dengan menentukan (Diatin dan Kusumawardany, 2010):

\section{Biaya Operasioal}

Biaya operasional didapatkan dengan menentukan total biaya tetap/fixed cost (FC) dan total biaya tidak tetap/variable cost (VC) yang dikeluarkan pada kegiatan perontokan. Biaya operasional dapat dihitung dengan Persamaan:

Biaya Operasional $=\mathrm{FC}+\mathrm{VC}$

Dimana:

FC : Biaya Tetap (Rp/tahun)

VC : Biaya Variabel (Rp/tahun)

Didapatkannya biaya operasional maka biaya pokok ditentukan dengan Persamaan:

Biaya pokok $=\frac{\text { Biaya operasional }(\mathrm{Rp} / \mathrm{tahun})}{\text { Kapasitas alat }(\mathrm{kg} / \mathrm{tahun})}$

Harga sewa alat ditetapkan sebesar Rp 400/kg biji kedelai sesuai dengan harga yang berlaku saat penelitian dilakukan.

Harga sewa alat ditetapkan sebesar Rp 400/kg biji kedelai sesuai dengan harga yang berlaku saat penelitian dilakukan.

Keuntungan dapat dihitung dengan menggunakan Persamaan:

$\Pi=$ TR-TC

Dimana:

$\Pi \quad$ : Keuntungan (benefit) Rp/tahun

TR : Penerimaan total (total revenue) Rp/tahun

TC : Biaya total (total cost) Rp/tahun

Break Event Point (BEP)

Untuk menentukan nilai break event point digunakan Persamaaan sebagai berikut:

$\mathrm{BEP}=\frac{\mathrm{FC}}{\mathrm{P}-\mathrm{VC}}$

Dimana:

FC : Biaya tetap (Rp/tahun)

$\mathrm{P} \quad$ : Biaya sewa alat $(\mathrm{Rp} / \mathrm{kg})$

$\mathrm{VC} \quad$ : Biaya variabel $(\mathrm{Rp} / \mathrm{kg})$ 
Tabel 1. Spesifikasi teknis mesin perontok multiguna

\begin{tabular}{lcc}
\hline \multirow{2}{*}{ Kondisi teknis } & \multicolumn{2}{c}{ Spesifikasi } \\
\cline { 2 - 3 } & Thresher A & Thresher B \\
\hline Diameter silinder perontok (mm) & 280 & 275 \\
Lebar silinder perontok (mm) & $550-695$ & $550-710$ \\
Jumlah baris gigi perontok & 8 & 6 \\
Jumlah gigi tiap baris & 8 & ada yang 6 ada yang 7 \\
Diameter gigi perontok (mm) & 10 & 10 \\
Tinggi gigi perontok (mm) & 60 & 55 \\
Jarak gigi ke saringan $(\mathrm{mm})$ & 20 & 20 \\
Diameter behel saringan (mm) & 6 & 5 \\
Jarak antar behel (mm) & 12 & 15 \\
Diameter puli (mm) & 30 & 300 \\
Lebar alat (mm) & 520 & 500 \\
Panjang alat (mm) & 785 & 820 \\
Tinggi hopper (mm) & 970 & 860 \\
Daya motor (HP) & 5.5 & 5.5 \\
Pemasangan gigi & Sejajar & Selang seling \\
Motor Pengggerak & Bensin 4 tak & Bensin 4 tak \\
Putaran silinder perontok (rpm) & $500-800$ & $500-800$ \\
\hline
\end{tabular}

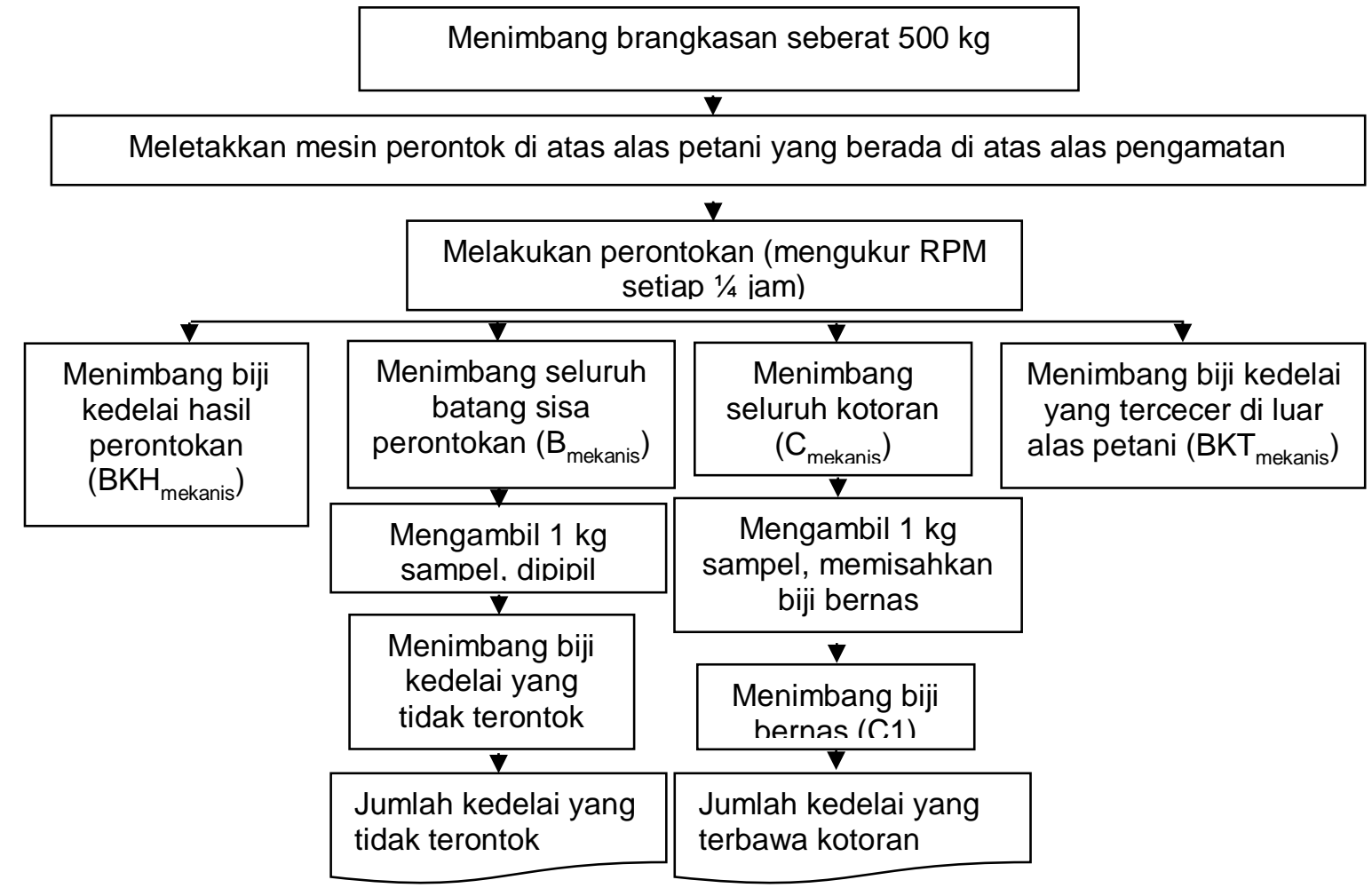

Gambar 1. Alur menentukan susut bobot/tercecer 


\section{Analisis Kelayakan}

Analisis kelayakan ditentukan dengan menggunakan kriteria net present value (NPV), internal rate of return (IRR), net $\mathrm{B} / \mathrm{C}$ dan nilai payback period. Untuk menghitung nilai masing-masing kriteria tersebut menggunakan Persamaan (Eva, dkk., 2014): Net present value (NPV)

$$
N P V=\sum_{t=0}^{t=n} \frac{B_{t}-C_{t}}{(1+i)^{t}}
$$

Keterangan:

$\mathrm{NPV} \quad$ : Net present value (Rp)

$\mathrm{B}_{\mathrm{t}} \quad$ : Net benefit pada suku bunga $\mathrm{i}$

$\mathrm{C}_{\mathrm{t}} \quad$ : Net Cost pada suku bunga $\mathrm{i}$

$\mathrm{t} \quad$ : Waktu (tahun) aliran kas

Kriteria :

NPV $>0:$ Proyek menguntungkan

NPV $<0$ : Proyek rugi

$\mathrm{NPV}=0$ : Proyek tidak untung tidak rugi (balik modal saja)

Internal rate of return (IRR)

$$
I R R=i^{\prime}+\frac{N P V^{\prime}}{N P V^{\prime}-N P V^{\prime \prime}}\left(i^{\prime \prime}-i^{i}\right)
$$

Keterangan:

i' : tingkat suku bunga menghasilkan NPV positif

i' : tingkat suku bunga menghasilkan NPV negatif

NPV' : NPV bernilai positif (pada suku bunga i')

NPV' : NPV bernilai negatif (pada suku bunga i')

Net B/C

$$
N e t \quad B / C=\frac{N P V(B-C) \text { positif }}{N P V(B-C) \text { negatif }}
$$

Keterangan:

NPV (B-C) negatif: Selisih NPV benefit dan NPV cost yang bernilai negatif

NPV (B-C) positif: Selisih NPV benefit dan NPV cost yang bernilai positif
NPV (B): NPV benefit pada tingkat suku bunga

NPV (C): NPV cost pada tingkat suku bunga

Kriteria: $\mathrm{B} / \mathrm{C}>1$ proyek dapat dikembangkan

Payback period

Payback Period $=\frac{\text { Investasi kas Bersih }}{\text { Aliran kas masuk bersih }} \times 1$ Tahun

\section{HASIL DAN PEMBAHASAN}

\section{Pengoperasian Alat perontok}

Dua mesin perontok (thresher) yang digunakan berasal dari desa Sindang Kasih, kecamatan Majalengka. Thresher A dan thresher B telah mengalami modifikasi dengan penambahan saringan yang berfungsi mengurangi kotoran yang tercampur dengan biji kedelai. Kedua thresher memiliki kapasitas yang berbeda. Kapasitas thresher A adalah 1,5-2,0 ton/jam dan thresher B 1,0-1,5 ton/jam.

Kapasitas pengumpanan, perontokan, penggunaan bahan bakar dan susut bobot dari hasil pengoperasian mesin perontok pada kecepatan putar silinder perontok 515-570 rpm dan 580-650 rpm dapat dilihat pada Tabel 2.

Dari data spesifikasi teknis (Tabel 1) dan pengoperasian alat, kedua thresher dikategorikan mesin yang berukuran kecil berdasarkan SNI 7866-2013 (Tabel 3). Kategori mesin perontok sangat diperlukan karena akan terkait dengan keekonomian alat, seperti luasan lahan yang tersedia, luas petakan sawah milik petani, dan topografi lahan yang berhubungan dengan kemudahan membawa alat ke lokasi perontokan.

Susut bobot rata-rata yang diperoleh dari pengoperasian mesin perontok adalah 0,68-3,1\%. Susut tersebut telah memenuhi SNI yang menstandarkan susut maksimal $20 \%$ (Tabel 3). 
Tabel 2. Kapasitas penggunaan bahan bakar dan susut bobot pada mesin perontok

\begin{tabular}{cccccc}
\hline Mesin & Rpm & $\begin{array}{c}\text { Kapasitas Pengumpanan } \\
(\mathrm{kg} / \mathrm{jam})\end{array}$ & $\begin{array}{c}\text { Kapasitas } \\
\text { Perontokan } \\
(\mathrm{kg} / \mathrm{j} a \mathrm{~m})\end{array}$ & $\begin{array}{c}\text { BBM } \\
(\mathrm{l} / \mathrm{jam})\end{array}$ & $\begin{array}{c}\text { susut bobot } \\
\text { rata-rata } \\
(\%)\end{array}$ \\
\hline \multirow{2}{*}{$\mathrm{A}$} & 1 & 513 & 226 & 0.61 & 0,68 \\
& 2 & 537 & 227 & 0.57 & 3,1 \\
\hline \multirow{2}{*}{$\mathrm{B}$} & 1 & 545 & 220 & 0.6 & 0,68 \\
& 2 & 596 & 244 & 0.65 & 3,1 \\
\hline
\end{tabular}

Keterangan: $\quad$ rpm 1*: kecepatan putar 515-570

rpm 2* : kecepatan putar 580-650

Tabel 3. Spesifikasi dan unjuk kerja mesin multiguna berdasarkan SNI 7866-2013

\begin{tabular}{|c|c|c|c|c|}
\hline \multirow{2}{*}{ Parameter } & \multirow{2}{*}{ Satuan } & \multicolumn{3}{|c|}{ Spesifikasi } \\
\hline & & Kecil & Sedang & Besar \\
\hline Daya motor penggerak & & $\begin{array}{r}\text { Motor ben } \\
\text { motor } \mathrm{d}\end{array}$ & $\begin{array}{l}\text { ngkah atau } \\
\text { langkah }\end{array}$ & $\begin{array}{c}\text { Motor diesel } 4 \\
\text { langkah }\end{array}$ \\
\hline \multicolumn{5}{|l|}{ Dimensi silinder perontok } \\
\hline - Lebar & $\mathrm{mm}$ & $500-750$ & $620-985$ & $720-985$ \\
\hline - Diameter & $\mathrm{mm}$ & $210-300$ & $275-350$ & $285-400$ \\
\hline $\begin{array}{l}\text { Putaran silinder perontok } \\
\text { dengan beban kerja }\end{array}$ & rpm & & $500-800$ & \\
\hline \multicolumn{5}{|c|}{ Kapasitas pengumpanan minimum } \\
\hline - Padi & $\mathrm{kg} / \mathrm{jam}$ & 1.000 & 1.600 & 3.000 \\
\hline - Jagung & $\mathrm{kg} / \mathrm{jam}$ & 1.200 & 2.000 & 3.000 \\
\hline - Kedelai & $\mathrm{kg} / \mathrm{jam}$ & 300 & 600 & 900 \\
\hline \multicolumn{5}{|c|}{ Kapasitas perontokan minimum } \\
\hline - $\quad$ Padi & $\mathrm{kg} / \mathrm{jam}$ & 500 & 800 & 1.500 \\
\hline - Jagung & $\mathrm{kg} / \mathrm{jam}$ & 600 & 1.000 & 1.500 \\
\hline - Kedelai & $\mathrm{kg} / \mathrm{jam}$ & 150 & 300 & 450 \\
\hline \multicolumn{5}{|l|}{ Persentase susut maksimum } \\
\hline - $\quad$ Padi & $\%$ & & 5 & \\
\hline - Jagung & $\%$ & & 15 & \\
\hline - Kedelai & $\%$ & & 20 & \\
\hline
\end{tabular}

\section{Analisis Ekonomi}

Analisis ekonomi merupakan analisis usahatani yang melihat dari sudut perekonomian secara keseluruhan. Menurut Aditya (2013), usahatani terdiri dari analisis penerimaan, biaya dan pendapatan. Analisis biaya dilakukan dengan menganalisa biaya tetap dan biaya tidak tetap yang akan dikeluarkan, biaya pokok serta break event point (BEP) dari kegiatan perontokan. Menurut Fronthea (2011), luas produksi atau tingkat produksi yang dilaksanakan, biaya yang dikeluarkan, serta pendapatan yang diterima sangat berpengaruh pada break event point (BEP) yang dihasilkan. Analisis ekonomi pada kegiatan perontokan kedelai di desa Sindang Kasih, kecamatan Majalengka dilakukan pertahunnya dengan dua masa tanam yaitu masa tanam di bulan Februari-April dan masa tanam di bulan Juni-Agustus. Hasil pertanaman kedelai yang dirontokkan oleh kedua thresher di bulan Februari-April mencapai 40 ha dan setiap hektarnya 
menghasilkan 1.5 ton biji kedelai yang telah dirontok. Hasil pertanaman kedelai yang dirontok di bulan Juni-Agustus mencapai 10 ha.

\section{Biaya Operasional dan BEP}

Data yang digunakan untuk menghitung biaya operasional dan BEP mesin perontok A dan B disajikan pada Tabel 4. Kapasitas perontokan dalam perhitungan sesuai dengan kapasitas yang diperoleh langsung dari pengoperasian alat di lapangan serta dikurangi susut bobot yang dihasilkan. Biaya operasional dan BEP yang dihasilkan dari kegiatan perontokan dapat dilihat pada Tabel 5.

Tabel 4. Data untuk menghitung biaya operasional thresher A dan B

\begin{tabular}{lccc}
\hline \multirow{2}{*}{ Spesifikasi } & Satuan & \multicolumn{2}{c}{ Nilai } \\
\cline { 3 - 4 } & & Thresher A & Thresher B \\
\hline Harga alat & $\mathrm{Rp}$ & 18.000 .000 & 15.000 .000 \\
Umur ekonomis alat & Tahun & 5 & 5 \\
Nilai sisa & $\%$ & 10 & 10 \\
Suku bunga & $\%$ & 15 & 15 \\
Jumlah operator & Orang & 1 & 1 \\
Upah operator & Rp/jam & $39.500-39.800$ & $38.500-43.000$ \\
Konsumsi BBM & liter/jam & $0,57-0,61$ & $0,6-0,65$ \\
Harga BBM & Rp/liter & 7.000 & 7.000 \\
Biaya pemeliharaan & Rp/hari & 20.000 & 20.000 \\
Kapasitas perontokan & $\mathrm{kg} /$ jam & $226-227$ & $220-244$ \\
Nisbah perontokan & Kg/Ha biji kedelai & 1.500 & 1.500 \\
Biaya moving alat & Rp/hari & 30.000 & 30.000 \\
Rata-rata hari kerja & Hari/tahun & 23 & 23 \\
Rata-rata jam kerja & Jam/hari & 7 & 7 \\
\hline
\end{tabular}

Tabel 5. Biaya operasional dan BEP mesin multiguna yang digunakan

\begin{tabular}{lcccccc}
\hline \multirow{2}{*}{ Analisis ekonomi } & \multirow{2}{*}{ Satuan } & \multicolumn{2}{c}{ Mesin A } & & \multicolumn{2}{c}{ Mesin B } \\
\cline { 3 - 4 } \cline { 6 - 7 } & & \multicolumn{1}{c}{$\mathrm{rpm} \mathrm{1*}$} & $\mathrm{rpm} \mathrm{2*}$ & & $\mathrm{rpm} \mathrm{1*}$ & \multicolumn{1}{c}{ rpm 2* } \\
\hline Biaya tidak tetap & Rp/tahun & 8.196 .970 & 8.200 .190 & & 8.024 .700 & 8.805 .550 \\
Biaya tetap & Rp/tahun & 4.860 .000 & 4.860 .000 & & 4.050 .000 & 4.050 .000 \\
Biaya operasional & Rp/tahun & 13.056 .970 & 13.060 .190 & & 12.074 .700 & 12.855 .550 \\
Penerimaan & Rp/tahun & 14.455 .430 & 14.165 .612 & & 14.071 .657 & 15.226 .478 \\
Keuntungan & Rp/tahun & 1.398 .460 & 1.105 .427 & & 1.996 .958 & 2.370 .928 \\
Biaya pokok & Rp/kg & 361 & 369 & & 341 & 327 \\
BEP & Ha/tahun & 18,7 & 19,2 & & 15,7 & 16 \\
\hline
\end{tabular}

Keterangan: $\quad$ rpm 1* : kecepatan putar 515-570 dengan susut 0,68\% rpm $2 *$ : kecepatan putar 580-650 dengan susut 3,1\%

\section{Analisis Kelayakan}

Analisis kelayakan dilakukan untuk mengambil keputusan layak tidaknya usahatani tersebut dikembangkan. Analisis kelayakan kegiatan perontokan ini dilakukan selama 5 tahun sesuai dengan umur ekonomis thresher yang digunakan. Kelayakan investasi dilakukan sesuai dengan kriteria net present 
value (NPV), internal rate of return (IRR), net $\mathrm{B} / \mathrm{C}$, dan nilai payback period dari data yang disajikan pada Tabel 5.

NPV diperoleh dari selisih present value benefit dan present value cost pada discount factor 15\%. Nilai NPV dari kegiatan perontokan menunjukkan net benefit yang diterima selama 5 tahun akan datang jika diukur dengan nilai sekarang adalah sebesar Rp 1.997.037 - Rp 2.979.329 pada thresher A dan Rp 5.270.338 - Rp 6.523.947 pada thresher B.

Untuk memperoleh internal rate of return (IRR) maka NPV investasi harus sama dengan nol pada suku bunga tertentu. Nilai IRR dalam kegiatan perontokan kedelai ini adalah 19,63-21,82\% pada thresher A dan 29,26-32,42\% pada thresher $\mathrm{B}$.

Net B/C merupakan nilai perbandingan antara NPV yang bernilai positif dengan NPV yang bernilai negatif. Nilai net $\mathrm{B} / \mathrm{C}$ didapatkan 1,11-1,17 pada thresher A dan 1,35-1,43 pada thresher $\mathrm{B}$.

Jangka waktu (payback period) yang dibutuhkan untuk mengembalikan investasi awal (initial investment) dapat dilakukan dengan cara menggunakan cash inflow yang dihasilkan investasi tersebut. Payback period dari investasi yang dilakukan adalah 4,0-4,3 tahun pada thresher A dan 3,1-3,3 tahun pada thresher B. Ini artinya bahwa dalam jangka waktu sekitar 4 tahun hingga 4 tahun 3 bulan untuk thresher A telah mampu mengembalikan investasi awal, sedangkan thresher B mampu mengembalikan investasi awal dalam jangka waktu 3 tahun 1 bulan hingga 3 tahun 3 bulan. Analisis kelayakan mesin perontok disajikan pada Tabel 6 .

Menurut Addo dkk., (2004), semakin tinggi kecepatan putar silinder perontok, maka kapasitas yang dihasilkan semakin tinggi pula. Akan tetapi, pengoperasian mesin perontok pada kecepatan putar yang tinggi tidak selamanya memberikan hasil yang baik, karena semakin tinggi kecepatan putar silinder perontok, maka susut bobot yang dihasilkan semakin besar. Hal ini dapat dilihat dari hasil analisis kelayakan pada thresher A (Tabel 6). Kecepatan putar silinder perontok 515-570 rpm (rpm 1*) menghasilkan NPV, IRR dan net $\mathrm{B} / \mathrm{C}$ lebih tinggi dibandingkan 580-650 rpm (rpm 2*) pada thresher A, sebaliknya pada thresher B kecepatan putar silinder perontok 515-570 rpm menghasilkan NPV, IRR dan net $\mathrm{B} / \mathrm{C}$ lebih rendah dibandingkan 580-650 rpm. Menurut Yahaya dkk. (2012), NPV, IRR, dan net $\mathrm{B} / \mathrm{C}$ akan meningkat dengan cara meningkatkan produksi/kapasitas. Perbedaan NPV, IRR, dan net B/C dari kedua mesin perontok ini mengharuskan user untuk lebih selektif dalam memilih mesin perontok yang akan digunakan.

Analisis kelayakan pada Tabel 6 menghasilkan kesimpulan bahwa kegiatan perontokan ini layak untuk dikembangkan. Adanya perubahan dan perkembangan hargaharga yang digunakan pada analisis ekonomi, maka perlu diuji kelayakan usaha dengan analisis sensitivitas. Harga-harga yang berpotensi berubah adalah harga BBM, moving alat, upah operator dan suku bunga. Walaupun upah operator sangat berpengaruh, tetapi upah operator tidak akan dianalisis sensitivitasnya karena upah operator pada usaha perontokan ini sebesar 50\% dari pendapatan setelah dikurangi dengan biaya variabel. Upah operator ini sudah cukup tinggi, apabila dinaikan kembali maka pemilik usaha perontokan akan mengalami kerugian.

Harga BBM dianalisis pada kenaikan harga sebesar 20\%. Hal ini didasarkan pada keputusan pemerintah bulan November 2014 yang menaikan harga BBM $\pm 20 \%$ yang mengakibatkan harga barang dan jasa menjadi meningkat. Meningkatnya harga BBM menagkibatkan harga moving alat dan suku bunga pun ikut meningkat. Harga moving alat dianalisis pada kenaikan harga sebesar $10 \%$ dari harga awal dan suku bunga pada angka $19 \%$.

Analisis sensitivitas kenaikan harga BBM sebesar 20\% (Tabel 7), biaya moving alat 
10\% (Tabel 8) dan kenaikan suku bunga 19\% (Tabel 9) menunjukkan bahwa usaha perontokan ini masih layak untuk dikembangkan. Akan tetapi, apabila suku bunga di atas $19 \%$, maka kegiatan perontokan untuk thresher A sudah tidak layak diusahakan.

Tabel 6. Analisis kelayakan mesin perontok masing-masing rpm

\begin{tabular}{cccccc}
\hline Thresher & RPM & $\begin{array}{c}\text { NPV } \\
(15 \%, 5 \text { tahun })\end{array}$ & $\begin{array}{c}\text { IRR } \\
(\%)\end{array}$ & $\begin{array}{c}\text { Net } \\
\text { B/C }\end{array}$ & $\begin{array}{c}\text { Payback period } \\
\text { (tahun) }\end{array}$ \\
\hline \multirow{2}{*}{ A } & $1^{*}$ & 2.979 .329 & 21,82 & 1,17 & 4,0 \\
& $2^{*}$ & 1.997 .037 & 19,63 & 1,11 & 4,3 \\
\hline \multirow{2}{*}{ B } & $1^{*}$ & 5.270 .338 & 29,26 & 1,35 & 3,3 \\
& $2^{*}$ & 6.523 .947 & 32,42 & 1,43 & 3,1 \\
\hline
\end{tabular}

Keterangan:rpm $1 *$ : kecepatan putar 515-570 dengan susut 0,68\% rpm $2 *$ : kecepatan putar 580-650 dengan susut 3,1\%

Tabel 7. Analisis sensitivitas kenaikan harga BBM $20 \%$

\begin{tabular}{cccccc}
\hline Thresher & RPM & $\begin{array}{c}\text { NPV } \\
(15 \%, 5 \text { tahun })\end{array}$ & $\begin{array}{c}\text { IRR } \\
(\%)\end{array}$ & $\begin{array}{c}\text { Net } \\
\text { B/C }\end{array}$ & $\begin{array}{c}\text { Payback period } \\
\text { (tahun) }\end{array}$ \\
\hline \multirow{2}{*}{ A } & 1 & 2.518 .427 & 20,79 & 1,14 & 4,2 \\
& 2 & 1.566 .358 & 18,64 & 1,09 & 4,5 \\
\hline \multirow{2}{*}{ B } & 1 & 4.816 .992 & 27,92 & 1,32 & 3,4 \\
& 2 & 6.032 .822 & 30,98 & 1,40 & 3,2 \\
\hline
\end{tabular}

Keterangan: rpm $1 *$ : kecepatan putar 515-570 dengan susut $0,68 \%$ rpm $2 *$ : kecepatan putar 580-650 dengan susut $3,1 \%$

Tabel 8. Analisis sensitivitas kenaikan harga moving alat $10 \%$

\begin{tabular}{cccccc}
\hline Thresher & RPM & $\begin{array}{c}\text { NPV } \\
(15 \%, 5 \text { tahun })\end{array}$ & $\begin{array}{c}\text { IRR } \\
(\%)\end{array}$ & $\begin{array}{c}\text { Net } \\
\text { B/C }\end{array}$ & $\begin{array}{c}\text { Payback period } \\
\text { (tahun) }\end{array}$ \\
\hline \multirow{2}{*}{ A } & 1 & 2.748 .030 & 21,36 & 1,15 & 4,1 \\
& 2 & 1.765 .738 & 19,14 & 1,10 & 4,3 \\
\hline \multirow{2}{*}{ B } & 1 & 5.039 .039 & 28,41 & 1,34 & 3,4 \\
& 2 & 6.292 .648 & 31,73 & 1,42 & 3,1 \\
\hline
\end{tabular}

Keterangan: $\quad$ rpm 1* : kecepatan putar 515-570 dengan susut $0,68 \%$ rpm $2^{*}$ : kecepatan putar 580-650 dengan susut 3,1\% 
Tabel 9. Analisis sensitivitas kenaikan suku bunga 19\%

\begin{tabular}{cccccc}
\hline Thresher & RPM & $\begin{array}{c}\text { NPV } \\
(15 \%, 5 \text { tahun })\end{array}$ & $\begin{array}{c}\text { IRR } \\
(\%)\end{array}$ & $\begin{array}{c}\text { Net } \\
\text { B/C }\end{array}$ & $\begin{array}{c}\text { Payback period } \\
\text { (tahun) }\end{array}$ \\
\hline \multirow{2}{*}{ A } & 1 & 1.136 .086 & 20,87 & 1,06 & 4,6 \\
& 2 & 240.098 & 19,60 & 1,01 & 4,9 \\
\hline \multirow{2}{*}{ B } & 1 & 3.489 .387 & 28,88 & 1,23 & 3,7 \\
& 2 & 4.632 .853 & 32,37 & 1,31 & 3,4 \\
\hline
\end{tabular}

Keterangan: rpm $1 *$ : kecepatan putar 515-570 dengan susut $0,68 \%$

rpm $2 *$ : kecepatan putar 580-650 dengan susut 3,1\%

Hasil analisis ekonomi dan kelayakan dari kegiatan perontokan di desa Sindang Kasih, kecamatan Majalengka menunjukkan bahwa dua thresher yang berukuran kecil ini cocok digunakan di daerah tersebut. Hal ini disebabkan karena kecamatan Majalengka merupakan perbukitan rendah dengan kemiringan $15-25 \%$.

\section{KESIMPULAN}

1. Pengkajian keekonomian mesin perontok multiguna untuk merontokan kedelai dengan harga sewa alat yang berlaku sebesar Rp 400/kg telah mencapai tingkat operasional yang menguntungkan dengan biaya pokok pengoperasian sebesar $\mathrm{Rp}$ 327/kg - Rp 369/kg. BEP tercapai pada luasan lahan 15,7 - 19,2 ha/tahun yang setara dengan $23.562-28.852 \mathrm{~kg}$ biji kedelai/tahun atau sebesar Rp 9.604.100 Rp 11.540.649/tahun.

2. Uji kelayakan dari kedua alat perontok multiguna yang dioperasikan menurut kriteria net present value (NPV), internal rate of return (IRR), net $\mathrm{B} / \mathrm{C}$ dan nilai payback period menunjukkan bahwa usaha perontokan ini layak untuk dikembangkan.

\section{DAFTAR REFERENSI}

Aditya, K.M., Heny, K., Suwarsinah, D., Ratna, W. 2013. Analisis Efisiensi dan Pendapatan Usahatani Kedelai di
Kabupaten Garut Provinsi Jawa Barat. J. Aplikasi Manajemen. 11: 1693-5241.

Addo, A., Bart Plange, A., Asuboah, R.A., Dzisi, K. 2004. Effect of different threshing cylinders on soybean quality. J. Science and technology 24 (2): 121-125.

[BPS] Badan Pusat Statistik. 2013. Distribusi Perdagangan Komoditi Kedelai di Indonesia 2013.

[BPS] Badan Pusat Statistik. 2017. Impor Kedelai Januari-April 2017.

Chenglong, H., Lingfeng, D., Qian, L., Wanneng, Y. 2011. Development of a whole-feeding and automatic rice thresher for single plant. J. Mathematical and Computer Modelling, 58 (2013): 684-690.

Diatin, I., Kusumawardany, U. 2010. Analisis kelayakan financial perluasan tambak budidaya udang vaname di Cantigi Indramayu. J. Akuakultur Indonesia. 9 (1): 77-83.

DIPERTA. 2013. Sentra produksi padi dan palawija. Dinas Pertanian Jawa Barat. http://diperta.jabarprov.go.id/index.php/ subMenu/548. Diunduh 22 Agustus 2014. 
Eva, M.R.M., Sukoso, Diana, A., Rene, C.K. 2014. Development Opportunity of Floating Net Cage (Fnc) SystemTrevally (Caranx Spp.) Culture Business in Amurang District, South Minahasa Regency, North Sulawesi, Indonesia. Journal of Business and Management 16 (9): 44-49.

Fronthea, S. 2011. Studi Kelayakan dan Efisiensi Usaha pengasapan ikan dengan asap cair limbah pertanian. J. Dinamika Ekonomi Pembangunan. 1 (1): 18-24.

Yahaya, A.T., Jayeola, C.O., Omueti, O., Taiwo, O. 2012. Economic evaluation of soy chocholate beverage dring. American Journal of Economics 2 (2): 16-19. 